\title{
Studies on the Biological Activity of Porcine Proinsulin
}

\author{
Norman R. Lazarus, Juan C. Penhos, Tomo Tanese, Leslie Michaels, \\ Raul Gutman, and LiLlian Recant
}

From the Diabetes Research Laboratory, Veterans Administration Hospital, Washington, D. C. 20422 and Georgetown University,

Washington, D. C. 20007

\begin{abstract}
A BSTRACT The biological activity of purified porcine proinsulin was investigated in rats. In vivo studies revealed that proinsulin produced a hypoglycemic response similar to insulin but of lesser magnitude. Hypophysectomized and adrenalectomized animals proved to be more sensitive to proinsulin than normal. In vitro studies with rat hemidiaphragm were consistent with the in vivo findings. No competition with insulin action could be demonstrated.

Experiments were carried out to determine whether proinsulin is converted to intermediate forms or insulin as a requisite to its biological activity. Labeled proinsulin injected in vivo or incubated in vitro remained intact by a variety of techniques (Sephadex column chromatography and polyacrylamide-gel electrophoresis).

An inhibitory action of Kunitz pancreatic trypsin inhibitor on proinsulin action in vitro was confirmed. No clarification of this effect could be ascertained.
\end{abstract}

\section{INTRODUCTION}

Proinsulin, a precursor molecule in the biosynthesis of insulin was first described in 1967 (1) and subsequently confirmed (2-5). The molecular weight of porcine proinsulin is 9082 and it is convertible to desalanyl insulin by controlled tryptic digestion. Porcine (6) and bovine (7) proinsulin have been isolated, purified, and their amino acid structure defined. Observations with isolated rat islets (5) showing release of proinsulin into the incubation medium under physiologic and pharmacologic conditions leading to the release of insulin support the likelihood that proinsulin may appear in the circulation. Clark and Steiner in a prior publication reported such an in vitro action for glucose (8). A "big insulin" in human and animal plasmas has been described (9). Though not conclusively proven, it seems likely that this material is indeed proinsulin. Efforts to specifically identify and measure proinsulin in the plasma have been

Received for publication 8 September 1969 and in revised form 16 October 1969. hampered by technical problems such as lack of human proinsulin standards and the likelihood that the antigenic "connecting peptide" of proinsulin is also in the circulation and must be differentiated from intact proinsulin (8-10).

The observations cited above have provoked many questions concerning the potential role of proinsulin in normal and diabetic subjects. The published reports to date indicate the biological activity of proinsulin in vitro and in vivo is small (11-13) compared with insulin. Shaw and Chance (11) have concluded from in vitro studies with rat muscle and adipose tissue, that the major biologic effects noted are associated with the conversion of proinsulin to insulin. A recent report (14) casts some doubt that such conversion takes place in vivo. However, no other evidence for in vivo or in vitro conversion of proinsulin has thus far been reported.

This paper is concerned with the investigation of the biological activity of proinsulin in both in vivo and in vitro systems. Experiments were designed to determine whether conversion of proinsulin to smaller molecules is essential for biological activity. In addition, the possibility that proinsulin might function as a competitive inhibitor of insulin was studied.

\section{METHODS}

Porcine proinsulin was obtained from Eli Lilly \& Co. ${ }^{1}$ The material had been prepared according to the procedure of Chance, Ellis, and Bromer (6). Biological activity was reported as $3.1 \mathrm{U} / \mathrm{mg}$ as measured by the mouse convulsion assay. Beef insulin, $5 \times$ recrystallized, was also obtained from Eli Lilly. The biological activity was $24.8 \mathrm{U} / \mathrm{mg}$ by mouse convulsion assay.

In order to assess the purity of the proinsulin preparations, particularly with regard to possible contamination with insulin, the following procedures were carried out. Proinsulin was subjected to polyacrylamide electrophoresis at $\mathrm{pH} 8.6$ as described by Davis (15), but modified according to The Canal Company, Rockville, Md., Technical Bulletin, September 1968, to produce an $18 \%$ small pore gel. Proinsulin iodinated with ${ }^{131} \mathrm{I}$ according to the method of Hunter and

\footnotetext{
${ }^{1}$ Thanks to Walter Shaw and to Elanco Products Co., a subsidiary of Eli Lilly.
} 
Greenwood (16) was purified by column chromatography on Sephadex G-50, equilibrated in $1 \mathrm{M}$ acetic acid. Tubes corresponding to the peak areas of the elution pattern were pooled and freeze dried. The iodinated proinsulin was then tested for purity by polyacrylamide electrophoresis. Finally, to insure that any small insulin contamination of proinsulin was inactivated, $0.65 \mathrm{mg}$ proinsulin was subjected to reduction in $7 \mathrm{M}$ urea and then reoxidation of disulfide bonds as described by Steiner and Clark (17). Reoxidation was allowed to proceed for $48 \mathrm{hr}$. To assure the effectiveness of the reduction $1.0 \mathrm{mg}$ of insulin was similarly treated. Both preparations were tested in vivo for hypoglycemic activity.

Assays in vivo of biological activity were carried out using normal male rats (Sprague-Dawley, 200-250 g). They were fasted overnight and then anesthetized with sodium amytal (40 $\mathrm{mg} / \mathrm{kg})$ for the assay. Specified amounts of proinsulin, insulin, combinations of the two, or reduced and reoxidized proinsulin and insulin were injected into the jugular vein. Samples for blood glucose (18) were taken from tail at $0,30,45,60,90,120$, and $180 \mathrm{~min}$. Rats were maintained under amytal anesthesia and warm throughout the procedure. Hypophysectomized and adrenalectomized rats $(100-200 \mathrm{~g})$ were studied in the fed state. These rats were anesthetized with amytal $(20 \mathrm{mg} / \mathrm{kg})$. Five rats were used for each dose level in all groups. The control group was injected with $1 \mathrm{ml}$ saline, the same volume being used for the administration of proinsulin and insulin. In addition to the above, the effects of Kunitz pancreatic trypsin inhibitor (KPTI), obtained from Worthington Biochemical Corporation, were investigated. Each rat received KPTI (10 mg/ $\mathrm{kg}$ ) with and without proinsulin. In a few experiments KPTI $(50 \mathrm{mg} / \mathrm{kg})$ was used. Antitrypsin activity of KPTI was tested against TPCK-treated trypsin according to the method described by Laskowski (19).

In order to determine whether proinsulin remains intact in the circulation or is degraded to insulin or intermediate forms, samples of proinsulin- ${ }^{131}$ I were injected intravenously into rats. At specified times aortic exsanguination was carried out. Samples were kept at $4^{\circ} \mathrm{C}$ and the plasma separated by centrifugation. Sephadex G-50 chromatography (in $1 \mathrm{M}$ acetic acid at $4^{\circ} \mathrm{C}$ ) was performed immediately. Tubes corresponding to the peak areas were then subjected to polyacrylamide-gel electrophoresis. The behavior of the injected proinsulin in the above systems was compared to uninjected iodinated proinsulin.

In vitro studies were conducted with paired rat hemidiaphragms (20). Rats (150 g) were fasted overnight, decapitated, and the hemidiaphragms were removed. They were incubated in $2 \mathrm{ml}$ Krebs-bicarbonate buffer, $\mathrm{pH} 7.6$, containing $200 \mathrm{mg} / 100 \mathrm{ml}$ gelatin and $200 \mathrm{mg} / 100 \mathrm{ml}$ glucose for a period of $60 \mathrm{~min}$ at $37^{\circ} \mathrm{C}$ in an atmosphere of $95 \%$ oxygen-5\% carbon dioxide. The effect of insulin or insulinlike materials was determined by measuring the glucose uptake from the medium ( $\mathrm{mg} / \mathrm{gm}$ wet weight per $\mathrm{hr}$ ). The effect of proinsulin was compared with that of insulin. The combination of proinsulin and insulin was also studied. In addition, the effect of KPTI $(200-400 \mu \mathrm{g} / \mathrm{ml})$ on the response of the hemidiaphragm to proinsulin was also studied.

Proinsulin- ${ }^{131} \mathrm{I}$ was incubated for $1 \mathrm{hr}$ in the presence of hemidiaphragms with and without KPTI. After incubation, the diaphragms were homogenized and the total number of counts associated with the tissue determined. The medium (2 cc) after purification on Sephadex columns was then subjected to polyacrylamide electrophoresis. Insulin- ${ }^{131}$ I was also studied in vitro.

\section{RESULTS}

\section{Biological activity of proinsulin in vivo}

Normal rats. Assuming a molecular weight of 9082 for proinsulin and 6000 for insulin, approximately equimolar solutions of each were prepared in $0.9 \% \mathrm{NaCl}$. Table I shows the schedule of doses used. Seven groups of five rats each were studied. One group received $1 \mathrm{ml}$ saline intravenously, three groups received insulin, and three groups received proinsulin. At all concentrations tested, proinsulin was active, although the depression in blood sugar was always greater with approximately equimolar amounts of insulin. The time course of hypoglycemia was not significantly different from that with insulin. It appears that $7.26 \times 10^{-6} \mathrm{M}$ proinsulin is not as active as $1.71 \times 10^{-6} \mathrm{M}$ insulin. This suggests that

TABLE I

In Vivo Hypoglycemic Effects of Proinsulin Compared with Insulin

\begin{tabular}{|c|c|c|c|c|c|c|c|c|c|}
\hline \multirow{2}{*}{$\begin{array}{l}\text { Material } \\
\text { injected }\end{array}$} & \multirow{2}{*}{$\begin{array}{l}\text { Amount } \\
\text { injected in } \\
1 \mathrm{ml} / \mathrm{rat}\end{array}$} & & \multicolumn{7}{|c|}{ Blood glucose levels, min after injection } \\
\hline & & & $\mathbf{0}$ & 30 & 45 & 60 & 90 & 120 & 180 \\
\hline & $m g$ & moles/liter & & & & $\mathrm{mg} / 100 \mathrm{ml}$ & & & \\
\hline Saline & - & - & $76 \pm 4.8$ & $74 \pm 4.5$ & $74 \pm 3.9$ & $73 \pm 5.6$ & $67 \pm 4.2$ & $67 \pm 4.5$ & $72 \pm 4.5$ \\
\hline Insulin & $\begin{array}{l}0.041 \\
0.010 \\
0.002\end{array}$ & $\begin{array}{l}6.84 \times 10^{-6} \\
1.71 \times 10^{-6} \\
3.33 \times 10^{-7}\end{array}$ & $\begin{array}{l}75 \pm 2.6^{*} \\
75 \pm 5.1 \\
70 \pm 4.8\end{array}$ & $\begin{array}{l}37 \pm 3.0 \\
41 \pm 4.1 \\
49 \pm 4.0\end{array}$ & $\begin{array}{l}20 \pm 1.0 \\
25 \pm 1.7 \\
49 \pm 2.0\end{array}$ & $\begin{array}{l}20 \pm 2.2 \\
32 \pm 1.0 \\
52 \pm 5.3\end{array}$ & $\begin{array}{l}26 \pm 2.0 \\
41 \pm 5.4 \\
58 \pm 4.1\end{array}$ & $\begin{array}{l}29 \pm 4.6 \\
45 \pm 4.5 \\
56 \pm 3.7\end{array}$ & $\begin{array}{l}49 \pm 5.2 \\
57 \pm 2.8 \\
71 \pm 3.6\end{array}$ \\
\hline Proinsulin & $\begin{array}{l}0.066 \\
0.016 \\
0.003\end{array}$ & $\begin{array}{l}7.26 \times 10^{-6} \\
1.76 \times 10^{-6} \\
3.30 \times 10^{-7}\end{array}$ & $\begin{array}{l}77 \pm 6.1 \\
86 \pm 4.5 \\
81 \pm 3.3\end{array}$ & $\begin{array}{l}36+3.7 \\
56 \pm 6.4 \\
66 \pm 4.0\end{array}$ & $\begin{array}{l}30 \pm 2.2 \\
46 \pm 6.8 \\
64 \pm 3.7\end{array}$ & $\begin{array}{l}39 \pm 3.6 \\
45 \pm 7.2 \\
63 \pm 3.9\end{array}$ & $\begin{array}{l}41 \pm 4.2 \\
49 \pm 7.1 \\
61 \pm 6.5\end{array}$ & $\begin{array}{l}55 \pm 9.6 \\
54 \pm 4.7 \\
63 \pm 4.1\end{array}$ & $\begin{array}{l}71 \pm 6.0 \\
62 \pm 4.0 \\
66 \pm 3.9\end{array}$ \\
\hline $\begin{array}{l}\text { Proinsulin } \\
\text { Insulin }\end{array}$ & $\left.\begin{array}{l}0.016 \\
0.002\end{array}\right\}$ & $\left.\begin{array}{l}1.76 \times 10^{-7} \\
3.33 \times 10^{-7}\end{array}\right\}$ & $86 \pm 2.2$ & $53 \pm 3.9$ & $44 \pm 2.6$ & $33 \pm 3.0$ & $38 \pm 2.6$ & $54 \pm 2.6$ & $72 \pm 4.8$ \\
\hline
\end{tabular}

* Mean of five rats \pm SEM. 
insulin is more than four times as active as proinsulin on a molar basis. In an effort to determine whether proinsulin alters the response of the animal to insulin, $3.33 \times 10^{-7} \mathrm{M}$ insulin and $1.76 \times 10^{-6} \mathrm{M}$ proinsulin were simultaneously injected into five rats. Table I shows the results. The combination was more hypoglycemic than either peptide alone.

Hypophysectomized and adrenalectomized rats. Since it is well known that there is increased sensitivity to insulin in hypophysectomized and adrenalectomized animals, it seemed pertinent to examine the responses of such animals to proinsulin. Table II records the responses of fed operated animals to two doses of proinsulin $(1.76 \times$ $10^{-6} \mathrm{M}$ and $\left.3.30 \times 10^{-7} \mathrm{M}\right)$. Each value represents the mean of five animals. It is apparent that hypophysectomy markedly increases the hypoglycemic response to proinsulin, while adrenalectomy does likewise, but is less effective than hypophysectomy.

Effect of reduction and reoxidation of disulfide bonds. To rule out obvious insulin or other contamination of the proinsulin, both unlabeled and iodinated proinsulin were examined on polyacrylamide-gel electrophoresis and Sephadex column chromatography. Insulin- ${ }^{121} \mathrm{I}$ was similarly studied. Fig. $1 \mathrm{~A}$ shows a single band for porcine insulin on polyacrylamide gel and indicates the location of insulin ${ }^{191} \mathrm{I}$ on Sephadex. Fig. $1 \mathrm{~B}$ shows the data obtained with iodinated proinsulin. On Sephadex chromatography, two radioactive peaks were seen (using Sephadex G-50 in 1 M acetic acid). On rechromatography, the first peak becomes progressively smaller. This material appears in the void volume of the column and probably represents albumin (used in the iodination procedure) to which free ${ }^{131} \mathrm{I}$ or denatured proinsulin is bound. The second peak is proinsulin and appears as a single band on polyacrylamide-gel electrophoresis. No insulin peak or band could be seen with this proinsulin preparation, although a 1-2\% contamination could not be positively ruled out. Table III shows the results obtained when unlabeled proinsulin and insulin were reduced in mercaptoethanol and $7 \mathrm{~m}$ urea, reoxidized, and subsequently tested for biological activity in vivo. Significant hypoglycemic activity was obtained with the proinsulin preparation, while essentially no activity occurred with the insulin preparation or the mercaptoethanol controls. The initial concentrations of proinsulin and insulin before reduction and reoxidation were approximately $3.42 \times 10^{-6} \mathrm{M}$. The hypoglycemic activity obtained with the reduced and reoxidized proinsulin was greater than that obtained with $1.76 \times 10^{-6} \mathrm{M}$ solution of untreated proinsulin (Table I). These data suggest a recovery of proinsulin of greater than $50 \%$ with essentially total loss of insulin activity. This recovery of biological activity is similar to that observed using immunoreactivity as a measure of proinsulin recovery (17) and supports the concept that the biological activity observed with proinsulin was not due to an insulin contaminant.

Reexamination of this preparation of proinsulin on polyacrylamide gel after approximately 1 month of storage in the frozen state $(1 \mathrm{mg} / \mathrm{ml}$ in $0.03 \mathrm{~N} \mathrm{HCl})$, revealed evidence of significant change (Fig. 2). A second band was now apparent migrating in a position consistent with either an intermediate form of proinsulin (21) or possibly desamido proinsulin (22) and representing a $20 \%$ contamination by densitometry. As a result of these observations, all proinsulin preparations were monitored by polyacrylamide gels before use in any of the experiments herein reported.

TABLE II

Response of Hypophysectomized and Adrenalectomized Rats to Proinsulin

\begin{tabular}{|c|c|c|c|c|c|c|c|c|c|c|c|c|c|c|}
\hline \multirow{3}{*}{$\begin{array}{c}\text { Min after } \\
\text { injection } 1 \mathrm{ml} \ldots\end{array}$} & \multicolumn{14}{|c|}{ Blood glucose } \\
\hline & \multicolumn{7}{|c|}{ Fed hypophysectomized rats } & \multicolumn{7}{|c|}{ Fed adrenalectomized rats } \\
\hline & 0 & 30 & 45 & 60 & 90 & 120 & 180 & $\mathbf{0}$ & 30 & 45 & 60 & 90 & 120 & 180 \\
\hline Proinsulin & \multicolumn{14}{|c|}{$m g / 100 m l$} \\
\hline $1.76 \times 10^{-6} \mathrm{M}$ & $\begin{array}{l}92^{*} \\
2.4 \ddagger\end{array}$ & $\begin{array}{l}34 \\
2.4\end{array}$ & $\begin{array}{l}29 \\
3.0\end{array}$ & $\begin{array}{l}22 \\
2.6\end{array}$ & $\begin{array}{c}18 \\
3.2\end{array}$ & $\begin{array}{c}16 \\
3.9\end{array}$ & $\begin{array}{c}15 \\
4.1\end{array}$ & $\begin{array}{l}80 \\
2.8\end{array}$ & $\begin{array}{c}63 \\
2.7\end{array}$ & $\begin{array}{c}44 \\
3.5\end{array}$ & $\begin{array}{l}35 \\
2.6\end{array}$ & $\begin{array}{l}40 \\
5.6\end{array}$ & $\begin{array}{l}40 \\
8.4\end{array}$ & $\begin{array}{l}40 \\
10.1\end{array}$ \\
\hline $3.30 \times 10^{-7} \mathrm{M}$ & $\begin{array}{l}86 \\
2.4\end{array}$ & $\begin{array}{l}40 \\
2\end{array}$ & $\begin{array}{l}33 \\
3\end{array}$ & $\begin{array}{l}28 \\
4.2\end{array}$ & $\begin{array}{l}29 \\
6.1\end{array}$ & $\begin{array}{l}35 \\
5.2\end{array}$ & $\begin{array}{c}42 \\
5.1\end{array}$ & $\begin{array}{l}80 \\
3.4\end{array}$ & $\begin{array}{c}71 \\
1.9\end{array}$ & $\begin{array}{c}62 \\
2.4\end{array}$ & $\begin{array}{c}53 \\
3.1\end{array}$ & $\begin{array}{c}58 \\
3.9\end{array}$ & $\begin{array}{l}66 \\
3.4\end{array}$ & $\begin{array}{l}73 \\
3.0\end{array}$ \\
\hline Saline & $\begin{array}{l}86 \\
2.2 \ddagger\end{array}$ & $\begin{array}{l}82 \\
1.7\end{array}$ & $\begin{array}{l}81 \\
1.7\end{array}$ & $\begin{array}{l}81 \\
2.0\end{array}$ & $\begin{array}{l}79 \\
1.7\end{array}$ & $\begin{array}{l}80 \\
2.4\end{array}$ & $\begin{array}{l}78 \\
1.4\end{array}$ & $\begin{array}{l}83 \\
3.6\end{array}$ & $\begin{array}{l}84 \\
3.5\end{array}$ & $\begin{array}{l}81 \\
2.0\end{array}$ & $\begin{array}{l}80 \\
3.0\end{array}$ & $\begin{array}{l}81 \\
2.5\end{array}$ & $\begin{array}{l}79 \\
1.1\end{array}$ & $\begin{array}{l}78 \\
1.3\end{array}$ \\
\hline
\end{tabular}

* Mean of five rats.

* SEM. 
Biological activity of proinsulin in vitro

Paired rat hemidiaphragms were incubated with varying amounts of proinsulin, insulin, and combinations of the two, and glucose uptake by the tissue was measured (Table IV). Proinsulin $(0.166 \mu \mathrm{g} / \mathrm{ml})$ had an insulin- like effect. This effect appeared to be roughly equivalent to $0.02 \mu \mathrm{g} / \mathrm{ml}$ of insulin $(500 \mu \mathrm{U} / \mathrm{ml})$ and comparable to the 8-fold bioactivity difference noted with mouse convulsion assay. The addition of $0.166 \mu \mathrm{g} / \mathrm{ml}$ proinsulin $(500 \mu \mathrm{U}$ insulin equivalents) to $0.02 \mu \mathrm{g} / \mathrm{ml}$ insulin
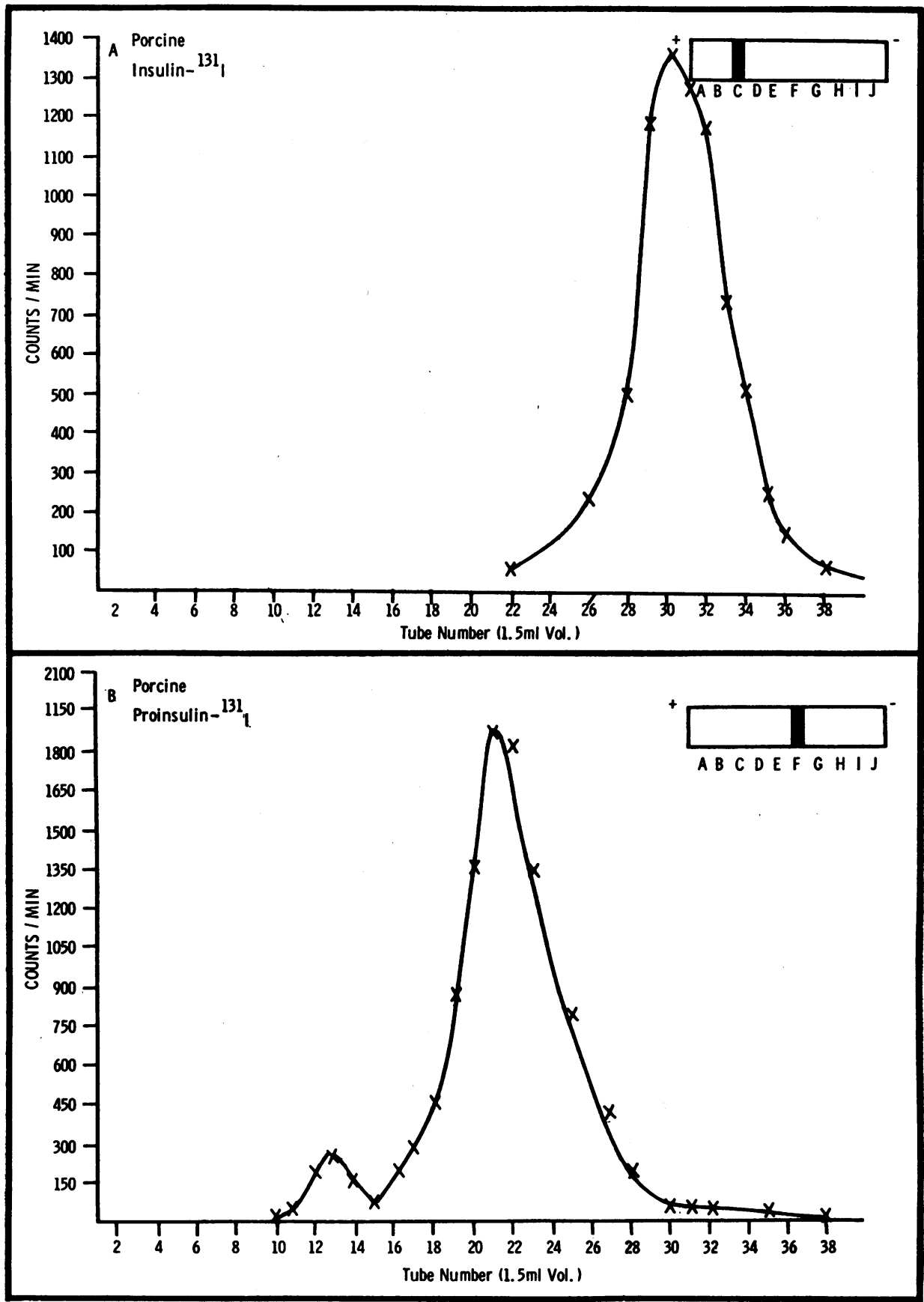

FIGURE 1 Chromatographic (Sephadex G-50, $1 \mathrm{M}$ acetic acid) and polyacrylamide-gel patterns of insulin ${ }^{-131} \mathrm{I}(\mathrm{A})$ and proinsulin (B). 
(500 $\mu \mathrm{U}$ insulin equivalents) produced an effect equivalent to $1000 \mu \mathrm{U} / \mathrm{ml}$ of insulin. Although the diaphragm system is not utilized here as a quantitative assay for insulin activity, certain conclusions from the paired data are warranted. Proinsulin has an insulin-like action and it neither inhibits nor potentiates insulin action on the diaphragm. Further, if conversion of proinsulin to insulin is necessary for activity, at least $\frac{1}{8}$ th of the proinsulin protein would have to be converted to insulin.

\section{Effect of KPTI on proinsulin action}

In vivo experiments in normal rats revealed no inhibitory effect of KPTI on proinsulin action (Table V). In three animals, as large a dose as $50 \mathrm{mg} / \mathrm{kg}$ of KPTI was similarly ineffective. Preparations, inactive in vivo, when tested with rat hemidiaphragms frequently proved to be capable of inhibiting the insulin-like action of proinsulin. Considerable variability of the inhibitory effect was observed which could not be correlated with antitrypsin activity (Table VI). On gel electrophoresis, KPTI was not homogenous. Three protein bands could be identified.

\section{Proinsulin conversion studies}

In order to determine whether proinsulin is converted to insulin, a tracer amount of chromatographically separated ${ }^{121} \mathrm{I}$-labeled proinsulin was injected intravenously into rats $(250-300 \mathrm{~g})$. Three animals were bled at $15 \mathrm{~min}$, three at $30 \mathrm{~min}$, and one at $45 \mathrm{~min}$ after injection. At these times, significant hypoglycemia could be observed with the previously described doses of unlabeled proinsulin. $2 \mathrm{ml}$ of plasma from each of these animals was chromatographed on Sephadex G-50 in 1 $M$ acetic acid and the eluted material was counted. A small peak appeared in the void volume while a single major peak which eluted in a position consistent with unchanged proinsulin was found at 15,30 , and $45 \mathrm{~min}$.

TABLE III

Effect of Reduction and Reoxidation on the In Vivo Biological Activity of Proinsulin and Insulin

\begin{tabular}{|c|c|c|c|c|}
\hline \multirow[b]{2}{*}{ Min after injection... } & \multicolumn{4}{|c|}{ Blood glucose } \\
\hline & $\mathbf{0}$ & 30 & 45 & 60 \\
\hline & \multicolumn{4}{|c|}{$\mathrm{mg} / 100 \mathrm{ml}$} \\
\hline $\begin{array}{c}\text { Mercaptoethanol } \\
3.6 \times 10^{-4} \mathrm{M}\end{array}$ & $79 \pm 0.01^{*}$ & $72 \pm 1.8$ & $71 \pm 1.6$ & $71 \pm 1.5$ \\
\hline $\begin{array}{l}\text { Insulin } \ddagger \\
\text { Reduced-reoxidized } \\
3.42 \times 10^{-6} \mathrm{M}\end{array}$ & $80 \pm 1.9^{*}$ & $74 \pm 2.6$ & $68 \pm 3.4$ & $69 \pm 3.5$ \\
\hline $\begin{array}{l}\text { Proinsulin } \ddagger \\
\text { Reduced-reoxidized } \\
3.60 \times 10^{-6} \mathrm{M}\end{array}$ & $81 \pm 2.2^{*}$ & $48 \pm 5.0$ & $33 \pm 2.0$ & $46 \pm 2.6$ \\
\hline
\end{tabular}

* Mean of five rats \pm SEM.

$\ddagger$ In mercaptoethanol $3.6 \times 10^{-4} \mathrm{M}$.

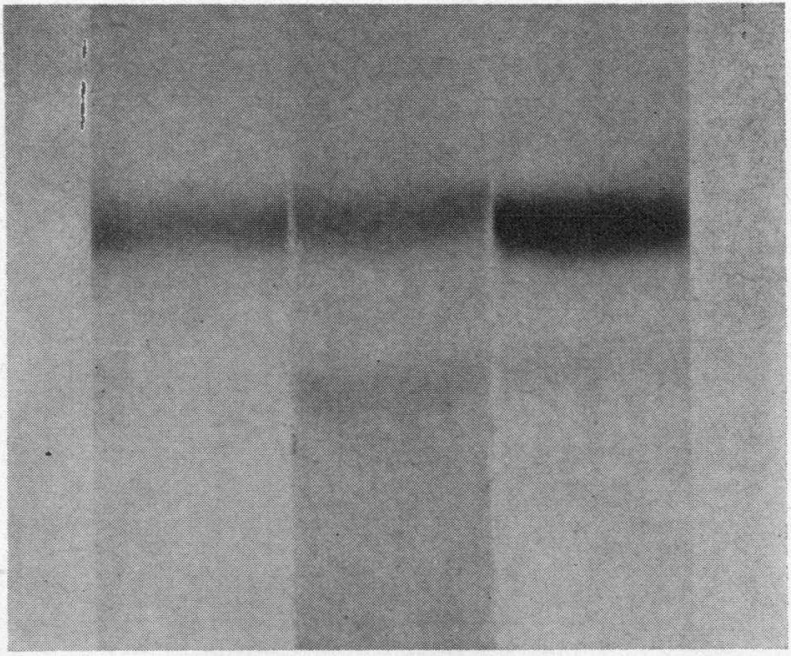

FIGURE 2 Polyacrylamide-gel patterns of several proinsulin preparations. (Positive poles at the bottom.) Note the presence of a single intact proinsulin band on the left. After 1 month, a second band appears migrating between proinsulin and insulin (insulin not shown on gel). The relative migration distances from the start of the running gel are: proinsulin $1.4 \mathrm{~cm}$, insulin $3.25 \mathrm{~cm}$, the second proinsulin band $1.9 \mathrm{~cm}$. Conditions of running as in reference 15 using an $18 \%$ gel.

No insulin peak was seen. Neither evisceration of rats nor bilateral nephrectomy produced any significant alteration in the single peak obtained from plasma.

Since intermediate forms of proinsulin have been identified (21) and have been found to elute from Sephadex with intact proinsulin, the possibility was considered that the single peak in rat serum might represent an intermediate form of proinsulin.

TABLE IV

Insulin-Like In Vitro Effects of Proinsulin on Rat Hemidiaphragm

\begin{tabular}{|c|c|c|c|c|c|}
\hline & & $\begin{array}{l}\text { Insulin } \\
\text { equiva- } \\
\text { lents }\end{array}$ & $\begin{array}{l}\text { Glucose } \\
\text { uptake }\end{array}$ & $\begin{array}{l}\text { Insulin- } \\
\text { like* } \\
\text { effect }\end{array}$ & $\begin{array}{c}\text { No. of } \\
\text { observations }\end{array}$ \\
\hline & $\mu g / m l$ & $\mu U / m l \ddagger$ & \multicolumn{2}{|c|}{$m g / g$ per $h r$} & \\
\hline $\begin{array}{l}\text { Buffer } \\
\text { Proinsulin }\end{array}$ & $\overline{0.166}$ & $\overline{500}$ & $\begin{array}{l}5.77 \\
7.73\end{array}$ & $\overline{1.96}$ & $\left.\begin{array}{l}12 \\
12\end{array}\right\} P \S=0.01$ \\
\hline $\begin{array}{l}\text { Buffer } \\
\text { Insulin }\end{array}$ & $\overline{0.02}$ & - & $\begin{array}{l}5.06 \\
7.16\end{array}$ & $\overline{+2.10}$ & $\left.\begin{array}{l}6 \\
6\end{array}\right\} P=0.01$ \\
\hline $\begin{array}{l}\text { Proinsulin } \\
\text { Insulin }\end{array}$ & $\begin{array}{l}0.166 \\
0.02\end{array}$ & $\begin{array}{l}500 \\
500\end{array}$ & $\begin{array}{l}7.36 \\
8.00\end{array}$ & - & $\left.\begin{array}{l}6 \\
6\end{array}\right\} P=\mathrm{NS}$ \\
\hline $\left.\begin{array}{c}\text { Proinsulin } \\
+ \\
\text { Insulin }\end{array}\right\}$ & $\left.\begin{array}{l}0.166 \\
0.02\end{array}\right\}$ & 1000 & 9.15 & - & $P=\mathrm{NS}$ \\
\hline Insulin & 0.04 & 1000 & 9.03 & - & $12 J$ \\
\hline
\end{tabular}

* Calculated as the difference from glucose uptake in buffer.

¥ Calculated from the bioactivity reported by mouse convulsion assay.

Paired hemidiaphragm data subjected to the paired $t$ test analysis. 
TABLE V

In Vivo Effect of KPTI* and Proinsulin on Blood Glucose

\begin{tabular}{|c|c|c|c|c|c|c|c|c|c|}
\hline \multirow[b]{2}{*}{ KPTI } & \multirow[b]{2}{*}{ PI } & \multirow[b]{2}{*}{ No. of rats } & \multicolumn{7}{|c|}{ Glucose } \\
\hline & & & $\operatorname{Min} \ldots 0$ & 30 & 45 & 60 & 90 & 120 & 180 \\
\hline$m g / k g$ & $m g / r a t$ & & \multicolumn{7}{|c|}{$\mathrm{mg} / 100 \mathrm{ml}$} \\
\hline 10.0 & 0.003 & $\begin{array}{c}6 \text { Average } \\
\text { SE }\end{array}$ & $\begin{array}{c}81 \\
4.9\end{array}$ & $\begin{array}{c}69 \\
6.4\end{array}$ & $\begin{array}{l}73 \\
1.4\end{array}$ & $\begin{array}{l}71^{*} \\
2.6\end{array}$ & $\begin{array}{l}67 \\
2.8\end{array}$ & $\begin{array}{l}77 \\
1.4\end{array}$ & $\begin{array}{l}77 \\
3.3\end{array}$ \\
\hline 10.0 & 0.016 & $\begin{array}{c}15 \text { Average } \\
\text { SE }\end{array}$ & $\begin{array}{l}82 \\
2.8\end{array}$ & $\begin{array}{l}52 \\
3.2\end{array}$ & $\begin{array}{c}47 \ddagger \\
2.8\end{array}$ & $\begin{array}{c}48 \\
3.3\end{array}$ & $\begin{array}{l}55 \\
2.6\end{array}$ & $\begin{array}{l}60 \\
2.0\end{array}$ & $\begin{array}{l}68 \\
2.4\end{array}$ \\
\hline 10.0 & 0.066 & $\begin{array}{c}7 \text { Average } \\
\text { SE }\end{array}$ & $\begin{array}{l}86 \\
3.6\end{array}$ & $\begin{array}{c}49 \\
3.3\end{array}$ & $\begin{array}{l}35 \\
2.6\end{array}$ & $\begin{array}{r}34^{*} \\
4.9\end{array}$ & $\begin{array}{l}50 \\
3.3\end{array}$ & $\begin{array}{l}56 \\
5.6\end{array}$ & $\begin{array}{l}68 \\
7.2\end{array}$ \\
\hline 10.0 & - & $\begin{array}{l}5 \text { Average } \\
\mathrm{SE}\end{array}$ & $\begin{array}{l}86 \\
2.8\end{array}$ & $\begin{array}{l}72 \\
4.4\end{array}$ & $\begin{array}{l}70 \\
3.5\end{array}$ & $\begin{array}{r}68^{*} \\
2.4\end{array}$ & $\begin{array}{l}69 \\
2.6\end{array}$ & $\begin{array}{l}70 \\
1.4\end{array}$ & $\begin{array}{l}65 \\
4.7\end{array}$ \\
\hline
\end{tabular}

* KPTI was dissolved in $1 \mathrm{ml}$ saline and administered intravenously.

$\ddagger$ Maximum falls in blood glucose levels when compared with those in Table $\mathrm{I}$ in which proinsulin was injected without KPTI, show no significant differences.

The 45 min peak was rechromatographed in $1 \mathrm{M}$ acetic acid and run on polyacrylamide-gel electrophoresis (Fig. 3). Intermediate forms of proinsulin move in a position between insulin and proinsulin. The labeled peak from rat serum moved in the position of the injected intact proinsulin- ${ }^{131} \mathrm{I}$.

Additional studies were carried out in which labeled proinsulin $(190,000 \mathrm{cpm} ; 0.013 \mu \mathrm{g} / \mathrm{ml}$ proinsulin protein) was incubated with paired hemidiaphragms for $60 \mathrm{~min}$, with and without $400 \mu \mathrm{g} / \mathrm{ml} \mathrm{KPTI}$. At the end of incubation, the tissues were washed in buffer, homogenized in $1 \mathrm{M}$ acetic acid and counted. 8000 cpm were found in each hemidiaphragm. This represents $1 / 24$ th of the total proinsulin. $(0.7 \%$ of these counts were not precipitable with $10 \%$ trichloroacetic acid.) If the diaphragm within $60 \mathrm{~min}$ was capable of con-

TABLE VI

Effect of KPTI on the Proinsulin-Induced Increment in Glucose Uptake Over Buffer*

\begin{tabular}{|c|c|c|}
\hline Proinsuli & $\begin{array}{l}\text { TI } \\
166 \mu \mathrm{g} / \mathrm{ml}\end{array}$ & $\begin{array}{c}+\mathrm{KPTI} \\
\text { Proinsulin } 0.166 \mu \mathrm{g} / \mathrm{ml}\end{array}$ \\
\hline \multicolumn{3}{|c|}{$m g / g$ hemidiaphragm per $h r$} \\
\hline No. & 21 & 21 \\
\hline Mean $\ddagger$ & +3.34 & +1.71 \\
\hline SEM & \pm 0.31 & \pm 0.28 \\
\hline
\end{tabular}

* The difference between hemidiaphragms incubated in buffer alone and in proinsulin in buffer; or incubation in buffer $+\mathrm{KPTI}(400 \mu \mathrm{g} / \mathrm{ml})$ vs. proinsulin in buffer $+\mathrm{KPTI}$.

$\ddagger$ KPTI partially inhibits the action of proinsulin $(P$ is $<0.001)$. This effect is not correlated with antitryptic activity. In some preparations, $1 \mathrm{mg}$ KPTI inhibited up to 8 $\mathrm{mg}$ trypsin; in others only $2.5 \mathrm{mg}$ trypsin. verting $\frac{1}{8}$ th of the $0.166 \mu \mathrm{g} / \mathrm{ml}$ of unlabeled proinsulin to insulin (Table IV), it would be anticipated that 0.013 $\mu \mathrm{g} / \mathrm{ml}$ of labeled proinsulin could be totally converted to insulin or an intermediate form of proinsulin. If these forms were sequestrated in the diaphragm tissue, then a greater number of counts should have been associated with the tissue. The medium was chromatographed on Sephadex G-50 in $1 \mathrm{M}$ acetic acid (Fig. $4 \mathrm{~A}$ ). A single peak eluting in the proinsulin position was obtained $(110,000 \mathrm{cpm} ; 61 \%$ recovery $)$. No peaks in the insulin position could be seen. A small peak (I) eluting with the void volume was obtained. The addition of these counts (I) to the tail portion of the elution (III) represented $7 \%$ of the total counts. KPTI showed no effect upon the elution pattern. Thus $93 \%$ of the proinsulin remained undegraded after $60 \mathrm{mi}$ nof incubation with diaphragm. The single proinsulin peak, including fractions where insulin would chromatograph, was lyophilized and placed on polyacrylamide gel. No evidence for insulin nor an intermediate form of proinsulin was obtained. There was no effect of KPTI on the gel patterns (Fig. 5).

Insulin- ${ }^{131} \mathrm{I}$ was also incubated with hemidiaphragms with and without KPTI as in the above experiment. Of the insulin- ${ }^{131} \mathrm{I}$ added, a recovery of $64 \%$ of the counts was obtained in both experiments. $5 \%$ of the total counts were sequestered in the diaphragm in the presence of KPTI of which $1.8 \%$ was not precipitable with $10 \%$ trichloroacetic acid. In the absence of KPTI, $11 \%$ of counts were found in the tissue of wh:ch $3.2 \%$ was not precipitable.

The Sephadex elution patterns of the two media are shown in Fig. 4 B. Counts in peaks I and III represent 
$26 \%$ of the total in the presence of KPTI and $34 \%$ in the absence of KPTI.

\section{DISCUSSION}

The observations reported here provide evidence that porcine proinsulin has an insulin-like action both in the intact rat and on isolated rat diaphragm. These data are confirmatory of those of Shaw and Chance (11) and others $(12,13)$. The studies showing retention of hypoglycemic action after reduction and reoxidation of proinsulin indicate that this hypoglycemic effect is not associated with any insulin contaminant. Both in vivo and in vitro proinsulin is significantly less active than insulin on a molar basis. Although neither system as utilized in these experiments provides a truly quantitative assay, the activity of proinsulin on the dia-

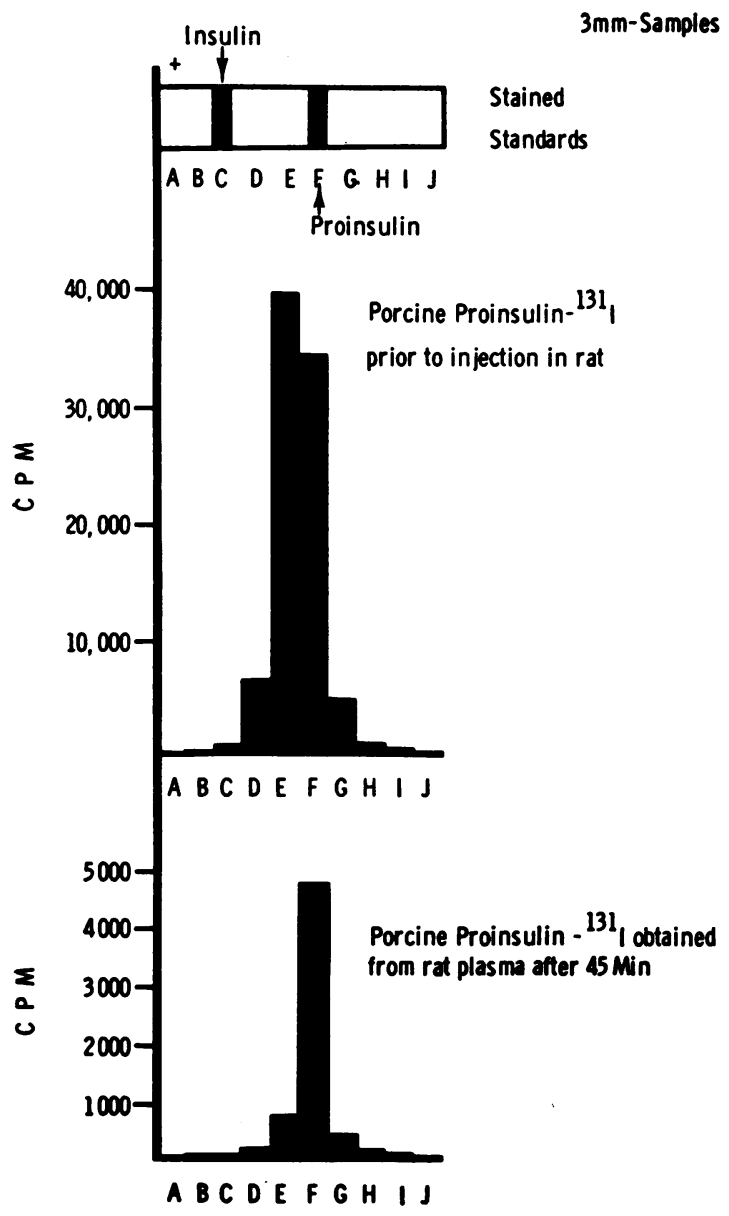

Figure 3 Polyacrylamide gel patterns of iodinated proinsulin before (control) and after intravenous injection into rat. Polyacrylamide gels stained, cut in 3-mm sections $(\mathrm{A}-\mathrm{J})$, and ${ }^{131} \mathrm{I}$ counts plotted. Note no significant difference in the gel pattern after injection of the labeled proinsulin in the rat. phragm is compatible with the data obtained in the mouse convulsion assay, namely, $\frac{1}{8}$ the activity of insulin on a milligram basis. In the diaphragm system, no inhibition of insulin action by proinsulin was noted despite a 10-fold excess of proinsulin protein over insulin. As one might anticipate with most hypoglycemic agents, removal of counter-insulin hormones increases the sensitivity of the animal to the agent. This was clearly demonstrated in the hypophysectomized and adrenalectomized rats studied. These animals in the fed state proved considerably more sensitive to the hypoglycemic action of proinsulin than normal animals in the fasted state. Although it has been reported (23) that the response of isolated cut hemidiaphragms to proinsulin was not altered by hypophysectomy, it should be noted that cut hemidiaphragms from hypophysectomized rats do not show an increased sensitivity to insulin in vitro, while intact diaphragms and intact animals do (24).

The mechanism by which proinsulin produces hypoglycemia appears to be a direct one in that no evidence for conversion of ${ }^{181}$ I-labeled proinsulin to insulin was observed. Plasma samples of proinsulin $-{ }^{13 \mathrm{~T}} \mathrm{I}^{2}$ obtained at 15,30 , and $45 \mathrm{~min}$ after intravenous injection showed no alteration in their Sephadex G-50 elution patterns when compared to control proinsulin samples. No label was seen in the insulin zone at any time. Further, polyacrylamide-gel electrophoresis ( $45 \mathrm{~min}$ plasma sample) reinforced the contention that proinsulin is unchanged in the circulation. The latter procedure should have been sufficiently sensitive to detect proinsulin intermediate had they been present.

In addition, no conversion of labeled proinsulin to insulin occurs when proinsulin is incubated in vitro with rat hemidiaphragms. In fact, $93 \%$ of the proinsulin remained intact, with only $7 \%$ being degraded in $60 \mathrm{~min}$. Of the degraded material, none eluted as insulin. Furthermore, polyacrylamide gel studies of the incubated proinsulin included that portion of the Sephadex peak which should have contained insulin. No insulin was detected. If the conversion capacity of the hemidiaphragm was of the order of $0.02 \mu \mathrm{g}$ of proinsulin $/ \mathrm{hr}$, all of the labeled proinsulin $(0.013 \mu \mathrm{g})$ should have been converted to insulin or an intermediate form, provided the iodinated proinsulin behaves similarly to the unlabeled molecule.

Since no insulin was found in vitro, the possibility was considered that rapid insulin breakdown might have occurred. Insulin breakdown has been reported to be as high as $70 \%$ in $90 \mathrm{~min}$ (25) of incubation with rat hemidiaphragms under certain conditions. In the experiments with insulin- ${ }^{131} \mathrm{I}$, there was indeed considerable degradation of insulin (33\%). However, $67 \%$ remained undegraded and the degraded smaller molecular species 
were clearly evident. If any conversion of proinsulin to insulin had occurred, $67 \%$ of the insulin should theoretically have been detectable.

Thus, molecular conversion of proinsulin does not occur in the circulation and seems also not to take place in vitro where a "hypoglycemic" action is demonstrable.

The effect of KPTI on proinsulin action is not clarified by the data obtained. The observations of Shaw and Chance (11) are confirmed in part in that in vitro inhibition of proinsulin action was observed with KPTI. No in vivo inhibition could be found. Further, KPTI had no effect on the degradation or polyacrylamide patterns of the labeled proinsulin incubated with diaphragm. The only positive observation made with KPTI indicated that it somewhat diminished the degra- dation of insulin in vitro ( $26 \%$ vs. $33 \%)$. However since no conversion of proinsulin occurred either during the period of in vitro incubation with diaphragm or in the rat plasma in vivo, it is difficult to ascribe any effect of KPTI to its antitryptic activity. Further, no correlation between antitryptic activity and in vitro action of KPTI obtained.

A number of isolated points relative to proinsulin studies should be made. First, with regard to the purity of the preparations, it should be noted that a single peak on Sephadex columns does not rule out the presence of intermediate forms of proinsulin. Polyacrylamide gels clearly show the presence of additional bands, despite single Sephadex peaks. Thus, in any proinsulin conversion studies, techniques other than Sephadex col-
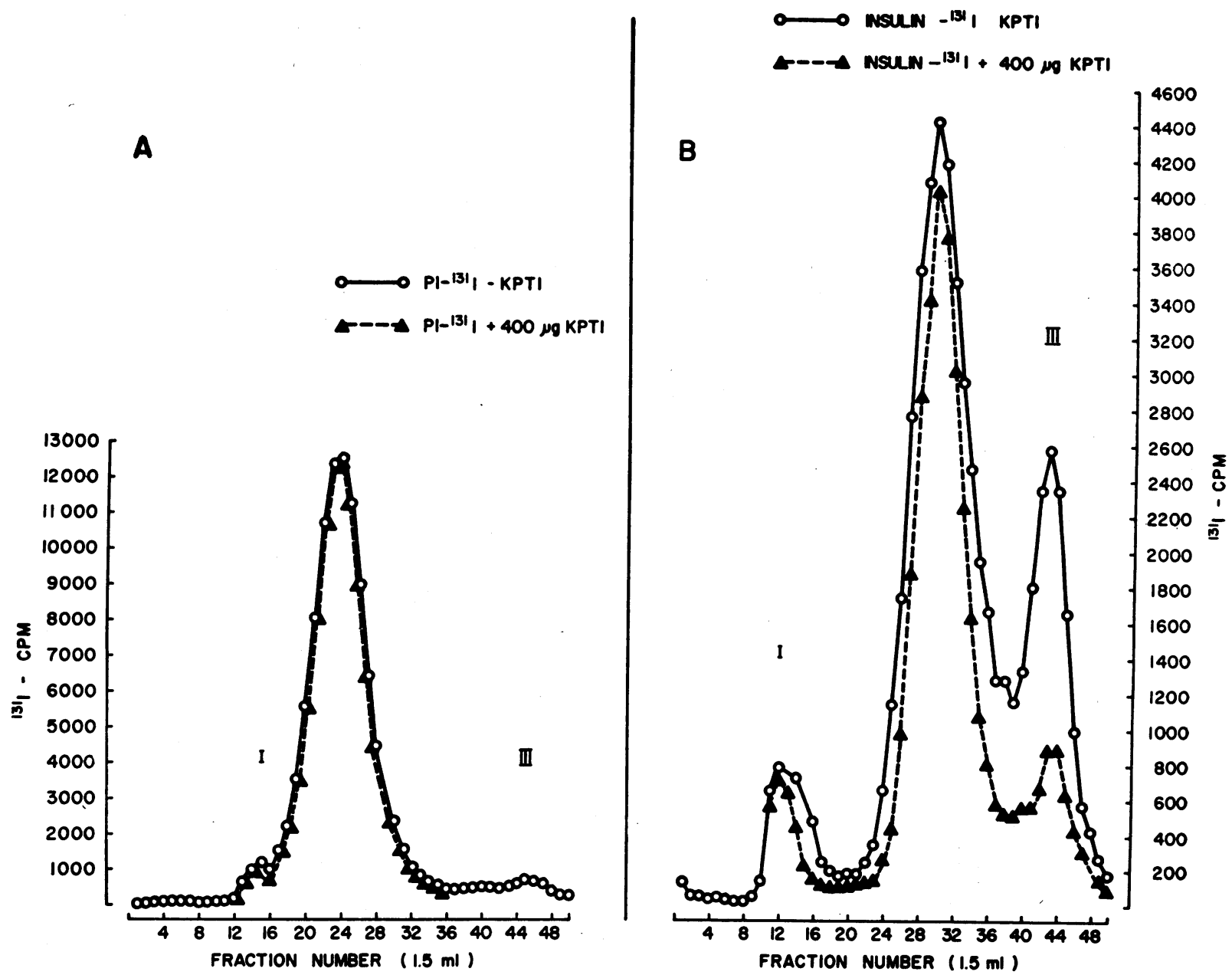

FIGURE 4 Elution patterns of proinsulin- ${ }^{131} \mathrm{I}$ and insulin- ${ }^{181} \mathrm{I}$ incubated with rat hemidiaphragm in the presence and absence of KPTI. Sephadex G-50 columns eluted with $1 \mathrm{M}$ acetic acid. Peak I represents material chromatographing in the void volume. The major peak in $A$ is intact proinsulin and in $\mathrm{B}$ is intact insulin. Peak III represents iodinated smaller molecular degradation products. 


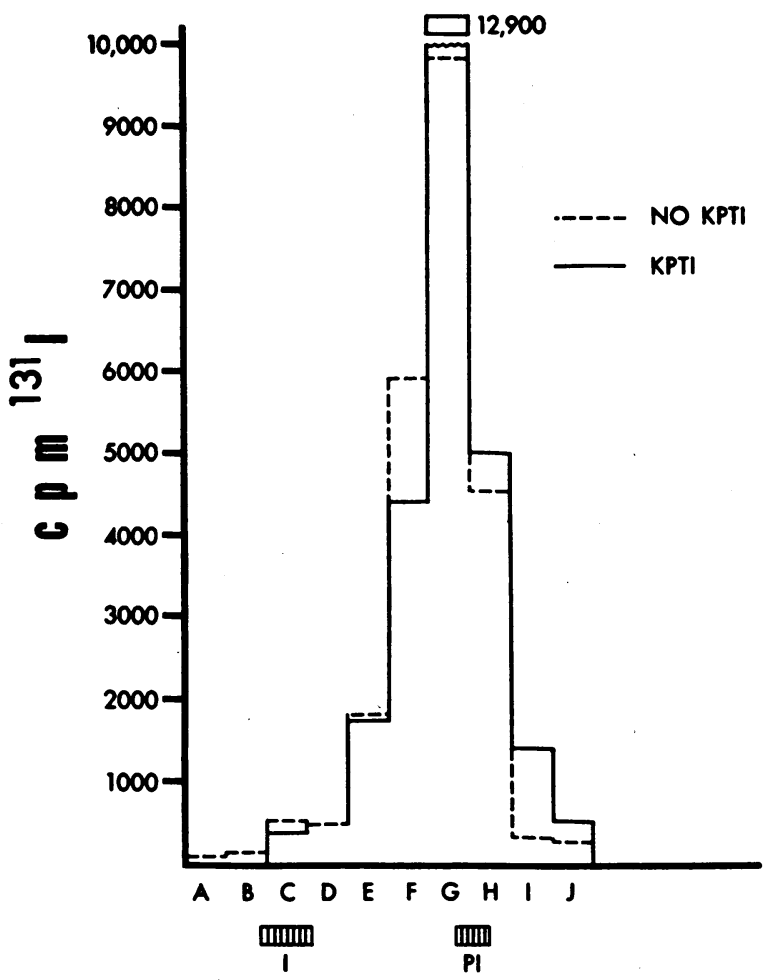

FIgURE 5 Proinsulin- ${ }^{121} \mathrm{I}$ incubated with rat hemidiaphragm for $60 \mathrm{~min} \pm \mathrm{KPTI}(400 \mu \mathrm{g} / \mathrm{ml})$. The incubation medium is shown after Sephadex chromatography, proinsulin peak lyophilization, and polyacrylamide-gel electrophoresis. The gel was cut in $3-\mathrm{mm}$ sections (A-J) and the ${ }^{181} \mathrm{I}$ counts plotted. Proinsulin is intact and KPTI has no effect on the pattern.

umns must be used to ascertain whether proinsulin remains intact. Secondly, prolonged storage of proinsulin may result in "spontaneous" appearance of bands moving on polyacrylamide in the position of proinsulin intermediates or more probably desamido proinsulin as suggested by the reports on insulin (22). As a result, any studies of proinsulin action require definition of the purity of the preparation.

Finally, the lack of effect of proinsulin on insulin action deserves mention. Since proinsulin does not compete with insulin and does not require conversion to insulin, it could be important in the pathophysiology of diabetes only if present in the plasma as the major "insulin" moiety. Thus far no such circumstance has been documented in diabetics, although it has been reported in patients with insulinoma (26). More precise measurements of proinsulin and its connecting peptide in diabetics may clarify the problem.

\section{ACKNOWLEDGMENT}

We wish to thank Miss Nancy Voyles for her excellent technical assistance.

\section{REFERENCES}

1. Steiner, D. F., D. Cunningham, L. Spigelman, and B. Aten. 1967. Insulin biosynthesis: evidence for a precursor. Science (Washington). 157: 697.

2. Chance, R. E., and R. M. Ellis. 1968. Isolation and characterization of porcine proinsulin. Fed. Proc. 27: 392. (Abstr.)

3. Grant, P. T., and K. B. M. Reed. 1968. Biosynthesis of an insulin precursor by islet tissue of cod (Gadus callarias). Biochem. J. 110: 281.

4. Tung, A. K., and C. C. Yip. 1968. The biosynthesis of insulin and "proinsulin" in fetal bovine pancreas. Diabetologia. 4: 68 .

5. Lazarus, N. R., T. Tanese, N. Voyles, and L. Recant. 1969. Patterns of proinsulin and insulin synthesis and secretion from isolated rat islets. Fed. Proc. 28: 573. (Abstr.)

6. Chance, R. E., R. M. Ellis, and W. W. Bromer. 1968. Porcine proinsulin: characterization and amino acid sequence. Science (Washington). 161: 165.

7. Nolan, C., E. Margoliash, and D. F. Steiner. 1969. Bovine proinsulin. Fed. Proc. 28: 343. (Abstr.)

8. Clark, J. L., and D. F. Steiner. 1969. Insulin biosynthesis in the rat: demonstration of two proinsulins. Proc. Nat. Acad. Sci. U. S. A. 62: 278.

9. Roth, J., P. Gorden, and I. Pastan. 1968. "Big insulin": a new component of plasma insulin detected by immunoassay. Proc. Nat. Acad. Sci. U. S. A. 61: 138.

10. Clark, J. L., S. Cho, A. H. Rubenstein, and D. F. Steiner. 1969. Isolation of a proinsulin connecting peptide fragment (C-peptide) from bovine and human pancreas. Biochem. Biophys. Res. Commun. 35: 456.

11. Shaw, W. N., and R. E. Chance. 1968. Effect of porcine proinsulin in vitro on adipose tissue and diaphragm of the normal rat. Diabetes. 17: 737.

12. Stoll, R. W., J. W. Ensinck, and R. H. Williams. 1969. Immunologic and biologic activities of the heterogeneous components of insulin. Diabetes. 18: 392.

13. Galloway, J. A., M. A. Root, R. E. Chance, R. P. Rathmacher, D. R. Challoner, and W. N. Shaw. 1969. In vivo studies of the hypoglycemic activity of porcine proinsulin. Diabetes. 18(Suppl. 1) : 341. (Abstr.)

14. Rubenstein, A. H., F. Melani, S. Pilkis, and D. F. Steiner. 1969. Proinsulin : secretion, metabolism, immunological and biological properties. Postgrad. Med. J. 45 (Suppl.) : 476.

15. Davis, B. J. 1964. Disc electrophoresis. II. Method and application to human serum proteins. Ann. N. Y. Acad. Sci. 121: 404.

16. Greenwood, F. C., and W. M. Hunter. 1963. The preparation of ${ }^{131}$ I-labelled human growth hormone of high specific radioactivity. Biochem. J. 89: 114.

17. Steiner, D. F., and J. L. Clark. 1968. The spontaneous reoxidation of reduced beef and rat proinsulins. Proc. Nat. Acad. Sci. U. S. A. 60: 622.

18. Nelson, N. 1944. A photometric adaptation of the Somogyi method for the determination of glucose. $J$. Biol. Chem. 153: 375.

19. Laskowski, M. 1955. Trypsinogen and trypsin. In Methods of Enzymology. S. P. Colowick and N. D. Kaplan, editors. Academic Press Inc., New York. 26.

20. Alp, H., and L. Recant. 1965. Studies of the insulininhibitory effect of human albumin fractions. J. Clin. Invest. 44: 870 . 
21. Steiner, D. F., O. Hallund, A. Rubenstein, S. Cho, and C. Bayliss. 1968. Isolation and properties of proinsulin intermediate forms, and other minor components from crystalline bovine insulin. Diabetes. 17: 725.

22. Berson, S. A., and R. S. Yalow. 1966. Deamidation of insulin during storage in frozen state. Diabetes. 15: 875.

23. Shaw, W. N. 1969. Further studies of the effect of porcine proinsulin in vitro. Diabetes. 18 (Suppl. 1): 341 . (Abstr.)
24. Kipnis, D. M. 1959. Regulation of glucose uptake by muscle: functional significance of permeability and phosphorylating activity. Ann. N. Y. Acad. Sci. 82: 354.

25. Piazza, E. U., C. J. Goodner, and N. Freinkel. 1959. A re-evaluation of in vitro methods for insulin bio-assay. Diabetes. 8: 459.

26. Lazarus, N. R., T. Tanese, and L. Recant. 1969. Proinsulin and insulin synthesis and release by human insulinoma. Diabetes. 18 (Suppl. 1): 340. (Abstr.) 